\title{
E-Waste Trading Impact on Public Health and Ecosystem Services in Developing Countries
}

\section{Ahsan Shamim ${ }^{1 *}$, Ali Mursheda $\mathrm{K}^{2}$, and Islam Rafiq ${ }^{3}$}

${ }^{1}$ Associate Professor of Environmental Science, Earth and Atmospheric Sciences Department, Metropolitan State University of Denver, CO, USA

${ }^{2}$ Adjunct Faculty, Biology Department, Metropolitan State University of Denver, CO, USA

${ }^{3}$ Soil, Water \& Bioenergy Program Director, Ohio State University South Centers, Piketon, $\mathrm{OH}, \mathrm{USA}$

\begin{abstract}
During recent year's accelerated global rise in Waste of Electric and Electronic Equipment (WEEE) and its indiscriminate disposal is becoming a foremost concern for human health and ecosystem services. With the rise in concerns on e-waste management and disposals practices, there are attempts to hold back e-waste generation and processing by a variety of regulatory instrument. Realistically there are substantial deficiencies in regulatory initiatives on worldwide trade, unlawful trafficking and improper handling of e-wastes. Currently, the center of attention on recent studies is primarily focusing on linkages of improper handling and consequent health effects on workers in the developing countries. Several studies emphasized on public health problems and reduced ecosystem services. An imminent concern of global calamity is expected, unless appropriate measures are not placed immediately into actions. These concerns demand a need to re-review the facts from recent research studies and suggest effective plans for collection, handling, disposal and remedy of e-wastes. An across-the-board review of available research and policy strategy is necessary to find a sustainable solution dealing with the global trafficking and trade of e-wastes.
\end{abstract}

Keywords: E-waste, trafficking, human health, recycling, regulatory compliance, Basel convention, Waste of electric and Electronic Equipment (WEEE), EU Directives.

\section{Introduction}

During last few decades, one special type of waste has raised a great concern in most of the developed- and in developing countries is the electronic waste. Currently, Waste Electrical and Electronic Equipment (WEEE) or e-waste is one of the fastest growing waste streams in the world [1]. Large quantities of e-waste represent an emerging environmental problem, as electrical and electronic waste equipment already constitutes more than $5 \%$ of municipal waste and is still growing fast in the developed countries [2]. Among the developed countries, United States produces largest volume of e-waste and it accounts for 1 to $3 \%$ of the total municipal waste generation. While in European Union (EU), the WEEE increases by 16 to $28 \%$ every five years, which is three times faster than that of average annual municipal solid waste generation. One of the UNEP studies estimate that the total amount of WEEE generation in EU ranges from 5 to 7 million metric tons annually or about 14 to $15 \mathrm{~kg}$ per capita, which is expected to grow at a rate of 3 to $5 \%$ per year [1]. The $2012 \mathrm{UN}$ report projected that by 2017 global e-waste will increase a further $33 \%$ from 49.7 million to 65.4 million metric tons annually [3].

The USEPA's report on e-waste statistics published in 2011 have reported that in 2009 there were 438 million new electronic products sold, 5 million short tons of electronic products were in storage, 2.37 million short tons of electronic products were ready for end-oflife management, and $25 \%$ of these tons were collected for recycling [4]. As fastest growing economies in the world, China and India are also experiencing exponential growth of Electrical and Electronic Equipment (EEE) consumption, which currently leads to a large volume of e-waste generation. In China, more than 5.1 million home appliances and 4.5 million personal computers are becoming obsolete each year [5]. In 2012 alone, China reportedly generated 11.1 million metric tons of e-waste as compared to 10 million tons of e-waste produced in the United States [6]. Besides domestic e-waste, being a developing country, over one million tons of e-waste from the U.S.,
Europe and other countries of the world are overflowing into China every year, taking advantage of the cheap labor costs and non-stringent environmental regulations [7]. It is assessed that one billion computers and accessories had been manufactured and subsequently discarded in 2008, and another one billion would be discarded worldwide within next 5 years [8].

The e-waste is a global environmental problem. Of the 20 million to 50 million metric tons of e-waste generated annually, it is estimated that 75 to $80 \%$ of that is shipped to developing countries especially in Asia and Africa for "recycling" and disposal [9]. Several studies have reported that a vast majority of the e-wastes is being exported to China and India. Moreover, other identified hot spots for e-waste destinations are Pakistan, Bangladesh, Ghana, Nigeria and Kenya. However, the handling and recycling techniques in these countries are often primitive and there is a little esteem for worker's safety or environmental protection $[8,10]$, which are illegal under the Basel Convention of 1992 or any other existing national environmental legislations [11]. In contrast, the WEEE recycling in developing countries is a daisy chain of processes which are carried out in the informal economy. Informal economies constitute a considerable amount of the gross national product (GNP) of the developing or economically transitional countries [12].

The e-waste has raised great concerns as many components in these products are hazardous, toxic and non-biodegradable. A prolong

*Corresponding author: Shamim A, Associate Professor of Environmental Science, Earth and Atmospheric Sciences Department, Metropolitan State University of Denver CO, USA, Tel: 303-556-4465; E-mail: sahsan@msudenver.edu

Received December 06, 2015; Accepted December 22, 2015; Published Decembe 29, 2015

Citation: Shamim A, Mursheda AK, Rafiq I (2015) E-Waste Trading Impact on Public Health and Ecosystem Services in Developing Countries. Int J Waste Resour 5: 188. doi: 10.4172/2252-5211.1000188

Copyright: ( 2015 Shamim, et al. This is an open-access article distributed under the terms of the Creative Commons Attribution License, which permits unrestricted use, distribution, and reproduction in any medium, provided the original author and source are credited. 
exposure of these toxic constituents in the environment is almost definite to cause a long term concern for both human and ecosystem health. Based on environmental concerns and scientific findings, several EU countries banned e-waste from landfills in the 1990s [13]. The concern about the effects of chemical exposure from e-waste products and e-waste recycling on public health is increasing despite the paucity of scientifically valid research findings. Reported adverse effects of e-waste on public health include: fetal loss, prematurity, low birth weight, and congenital malformations, abnormal thyroid function and thyroid development, neuro-behavioral disturbances, and Geno toxicity $[10,14]$.

The goal of this review paper is to assess the current status on generation and destination of WEEE, regulatory framework and its shortcomings, and likely human health and ecosystem effects summarized in related peer-reviewed research studies. This paper will also review the current sustainable e-waste management schemes, its outcomes, and possible solutions.

\section{E-waste Generation, Disposal and Regulations}

\section{Growth of e-waste and future global forecast}

Considerable global growth of e-waste has taken place in recent decades. According to UNEP reports, the estimated amount of annual global e-waste generation is around 20 to 50 million metric tons [15], about 1 to $3 \%$ of the global municipal solid waste production of 1636 million metric tons per year [16]. A recent UNU statistics indicates that the total annual global volume of WEEE - also referred to as e-waste is soon expected to reach 40 million metric tons [17]. There are varying estimates as to the amount of domestic, regional, and global e-waste produced. According to StEP (Solving the E-waste Problem Initiative), the 2012 global generation of e-waste totaled 45.6 million metric tons [18]. On the other hand, the Global E-Waste Management Market report (2011 to 2016) projected that the global volume is expected to reach 93.5 million metric tons in 2016 from 41.5 million metric tons in 2011, at Compound Annual Growth Rate (CAGR) of 17.6\% [19]. The USEPA has estimated a 5 to $10 \%$ annual increase in the generation of e-waste globally. Perhaps even more alarming is that only $5 \%$ of that amount is being recovered [4].

A WHO report recognized that the total amount of e-waste produced is exponentially increasing because of multiple and interlinked factors. Increasing consumer demand and a high obsolescence rate have led to frequent and unnecessary purchases of the EEE [20]. One of the major driving forces of growing e-waste problem is the short lifespan of most electronic products - less than two years for computers and cell phones $[21,22]$. Life span of computers has dropped in developed countries from six years in 1997 to just two years in 2005. Mobile phones have a lifespan of even less than two years [23]. The International Association of Electronics Recyclers (2006) projected that the current growth and planned obsolescence rates of the various categories of consumer electronics, somewhere in the proximity of 3 billion units which would be scrapped by 2010 or an average of about 400 million units a year. A recent UN University report estimated: by 2020 e-waste from old computers in South Africa and China will jump by 200 to $400 \%$ and by $500 \%$ in India compared to that of the 2007 levels. In 2012 alone, China reportedly generated 11.1 million metric tons of e-waste and the United States produced 10 million tons [6]. Even the least developed countries (LDC) like Senegal and Uganda are expecting e-waste flows from personal computers alone to increase 4 to 8 -fold by 2020 [24]. Research data have shown that electronic waste in Europe is growing at three times the rate of other municipal wastes [25]. The reliable and precise estimation on future e-waste generation varies from nation to nation, however, Khurrum et al. [26] analyzed e-waste problem providing an estimation of the amount of e-waste produced and recycled every year The estimate leads us to believe that by the year 2015, over 500 million units of e-waste will be disposed-off and slightly over 113 million units are expected to be recycled. Recent rise in electronic sales eliciting great concern of continued increase in e-waste. An annual report of the Consumer Electronic Association (CEA) presented a healthy-looking growth for sale of consumer electronic products. The US consumer electronics industry made overall shipment revenues above $\$ 173$ billion in 2008, while in July 2012 report estimates that industry sales will surpass $\$ 206$ billion this year. Sales growth is projected to continue into 2013 , when industry revenues will likely grow $4.5 \%$, reaching $\$ 216$ billion [27]. The global e-waste management market 2011-2016 report forecasted: The revenue generated from the e-waste management market is expected to grow from $\$ 9.15$ billion in 2011 to $\$ 20.25$ billion in 2016 at a growth rate of $17.2 \%$ from 2011 to 2016 [19]. According to a new report by Allied Market Research, the global e-waste Management Market would reach an amount of $\$ 49.4$ billion by 2020 , registering a Compound Annual Growth Rate (CAGR) of 23.5\% during 2014 to 2020 [28]. It is quite apparent that in different reports there are discrepancies and lacking in the correctness of the forecast data, however, most of the reports revealed a just beginning global rise of e-waste. The increase in e-waste is the visible symptom of the "make, consume, and dispose" culture that has permeated the developed world and is now spreading across the developing countries [29].

\section{Linkage of e-waste generation and GDP growth}

The economics of e-waste production and consumption have been constructed directly correlated with the GDP growth in most of the countries which was illustrated graphically (Figure 1) in a paper presented by Robinson [10]. Lu et al. [30] validated the relationship between China's GDP per capita, urbanization rate and e-waste generated from 2001 to 2012 (Figure 2). It is apparent that per capita e-waste generation is even higher than per capita GDP and is almost double the urbanization rate, indicating that e-waste generation will create a big challenge to the whole country. All these projected growth in the electronics sector clearly paint the grim picture and raise apprehension of unmanaged and unprocessed e-wastes, unless appropriate recycling measures are undertaken.

\section{Background of E-waste Recycling and Trade}

In 1991, the first electronic recycling system was implemented in Switzerland beginning with the collection of used and obsolete refrigerators. Over the years, all other electric and electronic devices were gradually added to the system. A legislation followed in 1998, and since January 2005, it has been possible to return all electronic wastes to the sales points and other collection points free of charge. There are two established PROs (Producer Responsibility Organizations): Swiss Economic Association for the Suppliers of Information, Communication and Organizational Technology (SWICO), mainly handling electronic waste and Swiss Foundation for Waste Management (SENS), mainly responsible for electrical appliances. The total amount of recycled e-waste exceeds $10 \mathrm{~kg}$ per capita per year [31]. In the 1990s, governments in the EU countries, Japan and several US states set up e-waste 'recycling' systems, but many countries do not have the capacity to deal with the sheer quantity of e-waste they generated annually or with its hazardous nature [32].

In many cases, the cost of recycling e-waste exceeds the revenue recovered from materials especially in countries with strict environment 


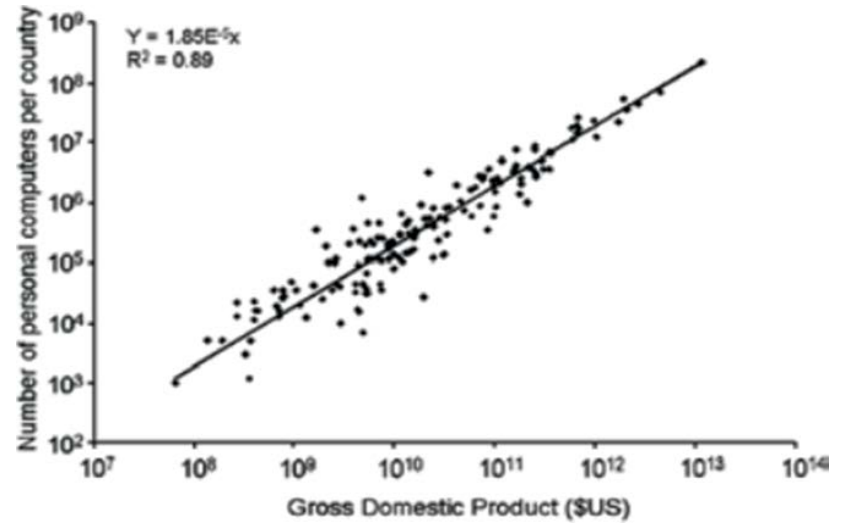

Figure 1: Number of PCs per country related to the country's GDP for 161 countries (Adapted from or Source: [10]).

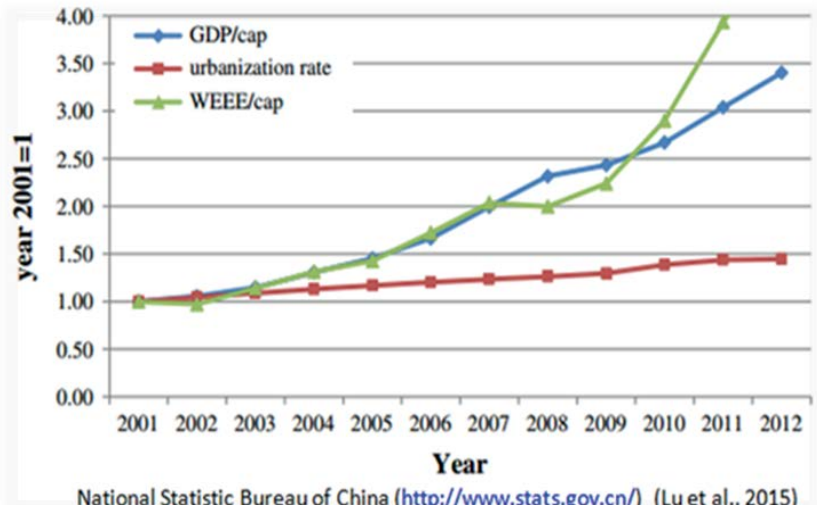

Figure 2: Urbanization rate in China with GDP/Cap, WEEE/cap Adapted from or Source: [30].

regulations. Therefore, e-waste mostly ends up dumped in countries where environmental standards are low or nonexistent and working conditions are poor. Historically, Asian countries have been a popular dumping ground for e-waste, but as regulations have tightened in these countries over time, this trade has moved to other regions of the world, particularly West Africa [33]. Several studies reported that one of the illegal recycling nucleus have grown in China over the years is a place named "Guiyu". The e-waste recycling reportedly began in Guiyu in the late 1980s. Laqiao is a town of 400,000 people in Taizhou and currently is the main e-waste recycling site in China. At least $10 \%$ of the population in Laqiao participates in e-waste recycling which first started in the 1970s $[18,34]$. A report by Toxics Link found that $70 \%$ of the e-waste collected at recycling units in New Delhi, India, was actually exported or dumped by developed countries, and about 50 to $80 \%$ of these e-wastes collected for recycling in the western US region are being exported to Asia [35,36]. About $90 \%$ of those e-wastes sent to China for recycling [35,36]. There are also e-waste recycling sites in Bengaluru and Delhi, India. In West Africa, e-waste recycling sites are located in Nigeria (Lagos) and Ghana (Accra, Agbogbloshie) [14,18,25].

The e-waste is informally processed in many countries of the world, but a high-volume of informal e-waste recycling has been reported in China, Ghana, Nigeria, India, Thailand, the Philippines, and Vietnam
[37]. Demand for e-waste recycling in Asia begins to grow when scrap yards found they could extract valuable metals such as copper, iron, silicon, nickel and gold, during the recycling process. A mobile phone, for example, is $19 \%$ copper and $8 \%$ iron [32]. Much of the informal e-waste recycling done in scrap yards and homes is done by children. The e-waste recycling in China is processed in the informal economy and constitutes a considerable amount of the gross national product (GNP) of the country [24]. Both the demand for recycled materials and the potential economic benefit are the main factors promoting the development of the disassembly (or recycling) industry for e-wastes [38]. Most of the literatures reported that informal waste recycling is carried out by poor and marginalized social groups who resort to scavenging and waste picking for income and survival [39].

\section{Current Management Practices and Regulatory Framework}

\section{E-waste management practices}

The existing management practices in US and Europe exerts greater economic impact on global trade and recycling due to generation of large volume of e-wastes. So far, legislation on WEEE is mainly driven by certain EU countries and their directive on WEEE. Most developing nations in the world are lagging behind in the development of similar regulations, in particular their enforcement [25]. In particular, various reports and studies by the mainstream Medias (e.g., Cbsnews.com, National Geographic, Scientific American) [cited in 40], environmental organization (e.g., Green peace [16], and researchers [26] have found primitive waste management practices in India and various countries in Africa and Asia. Existing e-waste recycling operations in Guiyu have gained a particular attention [40].

In the United States under most circumstances, e-waste can legally be disposed-off in a municipal solid waste landfill or recycled with little environmental regulatory requirements. The USEPA's 2011 report on e-waste shows that 2.4 million metric tons of e-waste were disposed in 2010 in the United States (Table 1). The USEPA report also elucidated that residential households store 5 times more computer products (by weight) than that in the commercial establishments. Approximately 2.37 million short tons of electronics are ready for end-of-life management, representing an increase of more than $120 \%$ compared to that in the 1999s [4]. As shown in Figure 3 that a large number of three major electronic devices were ready for end of life management in 2009, which eventually may add up the total volume as those are added in waste stream. Most recent report published by the USEPA in February 2014 shows; US generated 3.42 million metric tons of e-waste. Of this amount, only $29.2 \%$ was recycled, (up from $10 \%$ in 2000). The rest $71 \%$ of the e-waste was landfilled or incinerated [43]. Data presented in Figure 4 shows that a slow growth in generation of e-waste as well rise in recycling practices by weight in 2012 , i.e. $4.3 \%$ increase from previous year [42].

Increasing concerns about e-waste landfill disposal have led federal and state environmental agencies to encourage recycling in the United States. Although there may be limited data regarding how e-waste is managed, the consequences of e-waste export to the developing countries that handle it improperly are becoming increasingly evident. Reliable data regarding how much e-waste is generated, how it is managed, and where it is processed (either domestically or abroad) is largely unavailable. Because e-waste recycling is largely unregulated, virtually no data are available to track its fate [44]. The EU, Japan, South Korea, Taiwan and several US states have introduced legislation making producers responsible for their end-of-life products. The EU 
Citation: Shamim A, Mursheda AK, Rafiq I (2015) E-Waste Trading Impact on Public Health and Ecosystem Services in Developing Countries. Int J Waste Resour 5: 188. doi: $10.4172 / 2252-5211.1000188$

Page 4 of 12

\begin{tabular}{|c|c|c|c|c|}
\hline & Total Disposed ** (tons) & Trashed (tons) & Recycled (tons) & Recycling rate (\%) \\
\hline Computers & 423,000 & 255,000 & 168,00 & $40 \%$ \\
\hline Monitors & 595,000 & 401,000 & 194,000 & $33 \%$ \\
\hline Hard Copy Devices & 290,000 & 193,00 & 97,000 & $33 \%$ \\
\hline Keyboards and Mice & 67,800 & 61,400 & 6,460 & $10 \%$ \\
\hline Televisions & 1,040 & 864,000 & 181,000 & $17 \%$ \\
\hline Mobile Devices & 19,500 & 17,200 & 2,240 & $11 \%$ \\
\hline TV peripherals* & Not included & Not included & Not included & Not included \\
\hline Total (in tons) & $2,440,000$ & $1,790,000$ & 649,000 & $27 \%$ \\
\hline \multicolumn{5}{|c|}{ What's included here? } \\
\hline \multicolumn{5}{|c|}{ Computer products include CPUs, desktops and portables. } \\
\hline \multicolumn{5}{|c|}{ Hard copy devices are printers, digital copiers, scanners, multi-functions and faxes. } \\
\hline \multicolumn{5}{|c|}{ Mobile devices are cell phones, personal digital assistants (PDAs), smartphones, and pagers } \\
\hline \multicolumn{5}{|c|}{$\begin{array}{l}\text { *Study did not include a large category of e-waste: TV peripherals, such as VCRs, DVD players, DVRs, cable/satellite receivers, converter boxes, game } \\
\text { consoles. }\end{array}$} \\
\hline \multicolumn{5}{|c|}{$\begin{array}{l}\text { **"Disposed" means going into trash or recycling. These totals don't include products that are no longer used, but which are still stored in homes and } \\
\text { offices. }\end{array}$} \\
\hline
\end{tabular}

Table 1: E-Waste by the Ton in 2010 -Trashed or Recycled in USA.

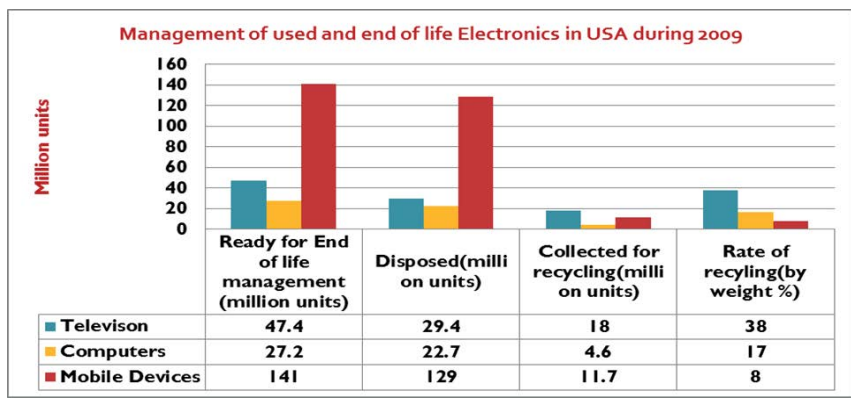

Figure 3: Management of used and end of life electronics in USA during 2009 [Data sources EPA].

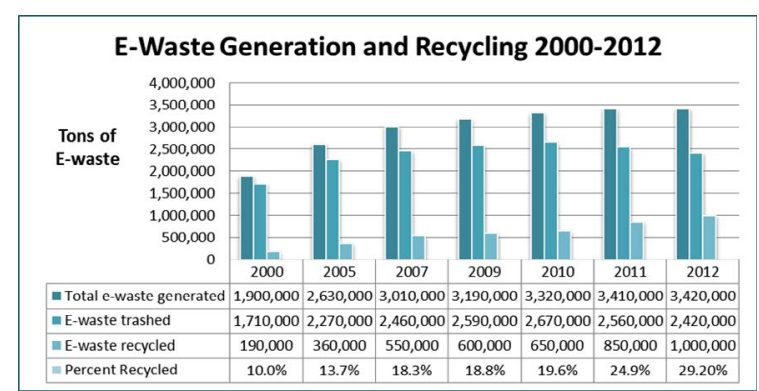

Figure 4: EPA data from "Municipal Solid Waste Generation, Recycling and Disposal in the United States, 2012 ," Feb 2014; These EPA numbers are for "selected consumer electronics" which include products such as TVs, VCRs, DVD players, video cameras, stereo systems, telephones, and computer equipment. [Adapted from 42]. has banned the use of certain hazardous substances in electrical and electronic products from July 2006, to facilitate safer recycling. However, the e-waste recycling sector in many Asian countries remains largely unregulated [23]. Restrictions on the use of certain chemicals are included in the EU Directive on Restrictions on Hazardous Substances - RoHS [45]. This directive has served as a useful guide for other developed countries, for example, China has recently drafted similar administrative measures [46].

\section{International, Regional and national efforts to manage E-waste}

Global management of WEEE falls under the Basel Convention on the Control of Trans- boundary Movements of Hazardous Wastes and their Disposal. The Convention was opened for signature on 22 March 1989, and enforced on 5 May 1992. Until 2006, the convention was ratified by 168 nations (Figure 5, Source Basel Convention). The sixth meeting of the Conference of the Parties to the Basel Convention (convened in 2002) recognized that the issue of e-waste recycling required urgent and in-depth supervision, particularly in the AsiaPacific regional countries. This program was further strengthened at the ninth meeting of the Conference of the Parties to the Basel Convention in 2006, with the adoption of the Nairobi Declaration on the Environmentally Sound Management (ESM) of Electrical and Electronic Waste (decision IX/6). By this decision, the secretariat was requested to facilitate work and activities on the ESM of e-waste, focusing on the management needs of the developing countries and countries with economies in transition. The Secretariat of the Basel Convention, in consultation with selected countries in this region and the Basel Convention Regional Centers in China (BCRC China), Indonesia (BCRC-SEA) and the South Pacific (SPREP), developed a proposal for a pilot project on the ESM of e-waste products [47]. Under the Basel Convention, e-wastes are classified under Annex VIII entries 
A1180, A1190, A1150 and A2010 and also under Annex IX as B1110. The e-wastes are characterized as hazardous wastes under the Convention when they contain reactive chemical components such as accumulators and other batteries, mercury switches, glass from cathode-ray tubes and other activated glass, PCB-containing capacitors or when contaminated with cadmium, mercury, lead or PCBs. Also, precious-metal ash from the incineration of printed circuit boards, LCD panels and glass waste from cathode-ray tubes and other activated glasses are characterized as hazardous wastes. To address the environmental issues related to the increasing trans-boundary movements of these wastes, and to ensure that their storage, transport, treatment, reuse, recycling, recovery and disposal is conducted in an environmentally sound manner, a proactive approach is essential. The plastics associated with e-wastes may need to be covered, under Annex II of the Basel Convention [48]. Despite the existence of these agreements and conventions, the transfer of WEEE from the United States, Canada, Australia, Europe, Japan and Korea to China, India, Bangladesh and Pakistan remains relatively high $[5,16$, 49]. Although Basel Convention regulates e-waste, it does not ban a country's right to export it entirely.

In the United States, concerns regarding the potential impact of exporting e-waste for processing in the developing countries have led to increased scrutiny from members of the public and environmental organizations, as well as members of Congress. The US Government Accountability Office (GAO) stated that concerns have grown, that some U.S. companies are exporting these e-wastes to the developing countries, where unsafe and/or unregulated recycling practices can cause serious health hazards and environmental problems. Currently, U.S. regulatory controls do little to stem the export of potentially hazardous used electronics, primarily due to (a) Narrow scope of regulatory control (U.S. hazardous waste regulations do not consider most used electronic products, such as computers, printers, and cell phones, as hazardous, instead, under U.S. law, only exports of CRTs are regulated as hazardous waste) and (b) Regulatory controls easily circumvented (The export of CRTs from the United States in apparent violation of the CRT rule seems widespread, despite adoption of the CRT rule in 2006). The USEPA has done a very little to enforce the CRT rule (EPA has taken few steps to enforce the CRT rule since the rule took effect in January 2007) [50]. On May 21, 2009, Representative Gene Green introduced H.R. 2595, a bill that would amend the Solid Waste Disposal Act (42 U.S.C. 6921) to establish certain e-waste export restrictions. There have also been several congressional hearings on issues associated with e-waste management, one of which specifically addressed issues associated with e-waste exports [51]. In July 2011, a tri-organizational

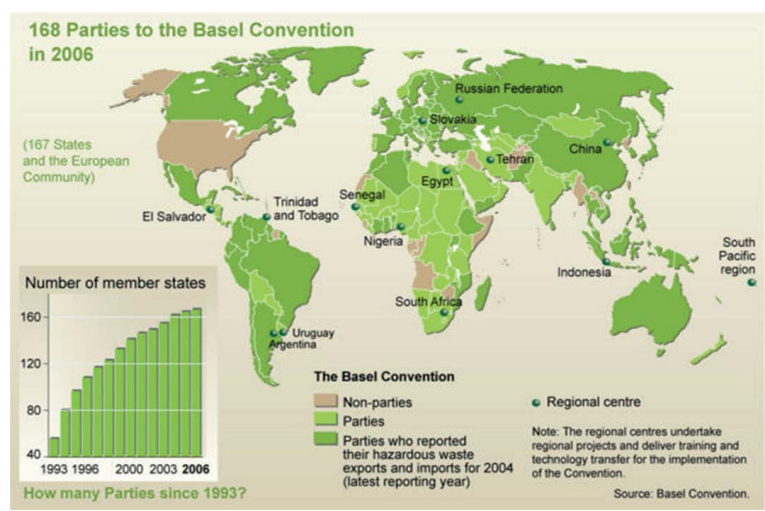

Figure 5: Parties in Basel Convention until 2006. (Source: Adapted from Basel Convention) taskforce released the National Strategy for Electronics Stewardship ("NSES" or "National Strategy"), establishing an innovative, flexible, pragmatic, and yet unified framework to evolve electronics stewardship. The actions identified in the NSES provide a roadmap to ensure that electronics are designed, purchased, and managed in a more sustainable manner, help protect human health and the environment from harmful effects associated with the unsafe handling and indiscriminate disposal of used electronics, and simultaneously promote new and innovative technologies of the future [52].

Another larger producer of e-waste, the EU countries follow the WEEE Directive of the European Parliament and of the Council (2002/96/EC), which entered into force in 2003. Despite extensive legislation targeting the e-waste problem, experience in the first few years of implementation of the WEEE Directive has shown that it is facing difficulties. Less than half of the collected e-waste is currently treated and reported according to the Directive's requirements [53]. Given that the processing of WEEE involves a variety of problems, European Directive PE-CONS 2/12, which is due to enter into force on 15 August 2018, provides for the grouping of all EEE into six categories instead of the current used ten categories (which remain valid from August 2012 until August 2018) [54].

Presently, most developing countries are lacking in regulatory instruments, especially those are the recipients of most of the e-waste products. Among those major e-wastes informal processing hubs, China and few African countries are in the process of formulating regulatory framework to prevent future environmental degradation as a result of growing e-waste generation and processing. Recently, the Chinese government issued a variety of laws, regulations, policies, standards, and technical guidance to manage and control the EEE Production and WEEE recycling [55]. Beginning July 1, 2004, collection, storage and disposal of hazardous wastes including e-waste require business licensing [56]. Measures for the Control of Pollution from Electronic Information Products, which is the counterpart of the EU RoHS directive, restricted the use of six hazardous substances (i.e. $\mathrm{Pb}, \mathrm{Hg}, \mathrm{Cd}$, $\mathrm{Cr}, \mathrm{PBB}$ or $\mathrm{PBDE}$ ) during the production, sale, and import of electronic information products in China destined for export [25,57]. However, there are few loopholes in this ordinance. For example, no deadline for the restriction has been fixed yet. Moreover, this regulation only applies to mainland China, not to Hong Kong or Macao; nevertheless, Hong Kong has already become the main receiving hub for used electrical and electronic products imported into China [55]. In 2008, the 'Administrative Measures on Pollution Prevention of WEEE' was enacted in order to prevent the pollution caused by the storage, transport, disassembly, recycling and disposal of e-waste. This policy also established a licensing scheme for e-waste recycling companies. Finally, in January 2011 the 'Regulation on Management of Recycling and Disposal of Waste Electrical and Electronic Equipment' was adopted. This regulation is similar to the EU WEEE Directive (Directive $2012 / 19 / \mathrm{EU}$ ) as it makes e-waste collection and recycling mandatory [58].

\section{Trade and Illegal Export beyond Regulatory Framework}

The INTERPOL research by Pollution Crime Working Group (PCWG) has uncovered that there are huge potential for informal networks of criminals to profit from the illegal export of e-waste to the developing countries. The two most common methods of illegal export are mislabeling containers to conceal e-waste and mixing waste with a legitimate consignment, such as end-of life vehicles [59]. The primary driver of this trade is that e-waste contains valuable components, is easy 
to source and relatively cheap to ship, and the risk of being caught is generally low [60]. In East Asia and the Pacific, the illicit trade appears to be driven by recycling for metals to be used in manufacturing. Within the region, China is the main destination for e-waste, despite the fact that the country banned the import of used electronic and electrical equipment in 2000. Globally, it is estimated that $80 \%$ of e-waste is shipped to Asia (including India) - with $90 \%$ of that amount destined for China [61]. An investigation carried out by a UK-based NGO, the Environmental Investigation Agency (EIA), revealed criminal syndicates involved in trafficking e-waste. These groups were also involved in other crimes such as theft, human trafficking, fraud, drugs and firearms trafficking, and money laundering [62]. Most of the studies recognized that illegal trade of e-waste is predominantly driven by high economic return, and the globalization of the illegal e-waste trade has increased corporate or "white-collar" crime. East Asia plays a prominent role in the illegal trade of both e-waste and ozone depleting substances (ODS). The Asia-Pacific region is a major recipient of illicit e-waste. It is estimated that up to 10 million metric tons of e-waste are traded illegally into and around the region annually, with a potential value of at least US $\$ 3.75$ billion. Considering that the global market for e-waste, including legal exports, has been predicted by the UNEP to be valued at around US \$ 11 billion by 2009 [1], the scale of the estimate of US $\$ 3.75$ billion of illegal e-waste in East Asia is reasonable [63]. A presence of the informal economy makes solid estimates of the value for the sector difficult. In another report by the UNEP using an estimate previously used by the INTERPOL of an average value of e-waste at US $\$ 500$ per metric ton [59], the range of e-waste handled informally or unregistered, including illegally, amounts to US \$ 12.5 to 18.8 billion annually [64]. In spite of national and international efforts, unaccounted e-waste in USA and EU countries is exported to developing countries. Although it is illegal in EU, such exports have been classified as legal recycling by the USEPA [16]. In the case of EU, despite strong legislations, a major source of e-waste which is illegally exported and dumped in developing countries. An estimated $75 \%$ of the e-waste generated in the EU, equivalent to 8 million metric tons a year, is unaccounted for [65]. It is believed that most of these 8 million metric tons were trafficked in several developing countries. The evolution of crime, even transnational organized crime, in the waste trading sector is a major threat. Whether the crime is associated with direct dumping or unsafe waste management, it is creating multi-faceted consequences that must be addressed urgently [64]. The first INTERPOL operation targeting the illegal trade of e-waste resulted in the seizure of more than 240 metric tons of electronic equipment and electrical goods and the launch of criminal investigations into some 40 companies involved in all aspects of the illicit trade [66]. Despite empirical data suffering from high uncertainties, the scale of the e-waste trade, its impacts across spheres, and its links to crime are difficult to contest. Although the crime itself often involves less structured and centralized groups than other crimes, the severity of its impacts and its relation with other crimes suggest the seriousness of this issue [58].

\section{Environmental and Human Health Impact}

Globalization of e-waste has adverse environmental and public health implications as the developing countries face economic challenges and lack the infrastructure for proactive management of hazardous wastes [67]. The degree of hazard posed to workers and the environment varies greatly depending on the individuals involved and the nature of operations. The short- and long-term effects of exposure to hazardous e-wastes are not fully understood, however, there are research conducted on the association between e-waste exposure and higher levels of chemicals and metals in human-derived biological samples $[18,68,69]$. What is known is that the pollution generated by e-waste handling and processing brings about toxic or genotoxic effects on the human body, threatening the health not only of workers but also of current residents and future generations living in the local environment [70]. Most people are uninformed of the possible negative impact of the rapidly increasing use of electronic devices. When these products are placed in landfills or incinerated, they pose health risks due to the hazardous materials they contain [71]. Computers and display units contain a significant amount of diverse chemical compounds that are hazardous to human health if they are not disposed of properly. Monitors and televisions compose $40 \%$ of total lead and $70 \%$ of all heavy metals found in landfills. These heavy metals and other toxins that can leach into the soil and groundwater from landfills, evaporate into the air, and enter the air through incineration [72]. Many researchers have indicated that different types of chemicals and pollutants released from e-waste into the environment as a consequence improper handling and processing $[21,35,69,73,74]$ and they can accumulate in the human body through various pathways. Inhalation of contaminated air and dust is believed to be one of most important pathways. Some pollutants such as PCDD/Fs, PCBs, PBDEs, PAHs, cadmium, chromium, lead, and arsenic have been identified in atmospheric particles in- and around the e-waste dismantling areas in China $[21,69,75]$. Long-range transport of pollutants has also been observed, which suggests a risk of secondary exposure in remote areas. Atmospheric pollution due to burning and dismantling activities seems to be the main cause of occupational and secondary exposure [25]. The BAN studies have identified a range of potential occupational safety hazards including silicosis, toxic exposure to dioxins, mercury and other metals and carcinogens through inhalation of fumes while processing e-waste or from local drinking water and food sources contaminated by e-waste by-products [76]. The potential adverse health effects of exposure to e-waste have been reviewed recently and may take account of changes in lung function, thyroid function, hormone expression, birth weight, birth outcomes, childhood growth rates, mental health, cognitive development, cytotoxicity, and genotoxity [18,37,77]. The toxicity of many individual substances found in e-waste is well documented in several studies, however, the toxicity of the mixtures of substances likely to be encountered through e-waste recycling is less well known. Heavy metals and halogenated compounds appear to have a major influence on public health [18,57]. Direct exposure entails skin contact with harmful substances, the inhalation of fine and coarse particles, and the ingestion of contaminated dust. Individuals who directly engage in e-waste recycling with poor protection incur high levels of direct, occupational exposure [18,34,78]. In most of the recycling operations involve burning the plastic coverings of materials to extract metals for scrap, openly burning circuit boards to remove solder or soaking them in acid baths to strip them for gold or other metals. Acid baths are then dumped into surface water which severely impact fresh water ecosystems. Despite the fact that uncontrolled open strong acid leaching of e-waste is officially banned and considered illegal, this practice is on-going in Guiyu, China. One such operation was identified during field sampling. Data presented in Table 2 have shown show comparison of e-waste processing site in China with some riverine systems in Australia [79] and the USA [80]. Data indicated that two rivers in Guiyu, Lianjian and Nanyang were considerably enriched with $\mathrm{Cd}, \mathrm{Co}, \mathrm{Cu}, \mathrm{Ni}, \mathrm{Pb}$ and $\mathrm{Zn}$. The Pearl River Economic Zone is one of the largest light industrial bases in China, and "dissolved" metal concentrations in urban and rural beaches of the Pearl River were determined by Ouyang et al. [81]. It was found that Nanyang river of Guiyu was noticeably more polluted with $\mathrm{Cd}, \mathrm{Co}, \mathrm{Cu}, \mathrm{Ni}, \mathrm{Pb}$ and $\mathrm{Zn}$ 


\begin{tabular}{|c|c|c|c|c|c|c|c|}
\hline Locations & $\begin{array}{l}\text { Cd } \\
\text { (Mean } \pm \\
\text { SD) }\end{array}$ & $\begin{array}{l}\mathrm{Pb} \\
\text { (Mean } \pm \\
\mathrm{SD} \text { ) }\end{array}$ & $\begin{array}{l}\text { Co } \\
\text { (Mean } \pm \\
\text { SD) }\end{array}$ & $\begin{array}{l}\text { Cu } \\
\text { (Mean } \pm \\
\text { SD) }\end{array}$ & $\begin{array}{l}\mathrm{Ni} \\
\text { (Mean } \pm \\
\text { SD) }\end{array}$ & $\begin{array}{l}\text { Zn } \\
\text { (Mean } \pm \\
\text { SD) }\end{array}$ & Refs \\
\hline Lianjiang, Guiyu & $\begin{array}{l}0.091 \pm \\
0.010\end{array}$ & $\begin{array}{l}1.48 \pm \\
0.09\end{array}$ & $\begin{array}{l}0.86 \pm \\
0.096\end{array}$ & $\begin{array}{l}7.80 \pm \\
1.70\end{array}$ & $36.6 \pm 6.2$ & $\begin{array}{l}30.6 \pm \\
4.2\end{array}$ & Coby S et al., 2007[82] \\
\hline Nanyang, Guiyu & $\begin{array}{l}0.315 \pm \\
0.032\end{array}$ & $\begin{array}{l}1.81 \pm \\
0.30\end{array}$ & $\begin{array}{l}3.62 \pm \\
0.82\end{array}$ & $\begin{array}{l}50.8 \pm \\
10.0\end{array}$ & $52.4 \pm 7.6$ & $\begin{array}{l}106 \pm \\
10\end{array}$ & Coby S et al., 2007 [82] \\
\hline $\begin{array}{l}\text { Hawkesbury-Nepean } \\
\text { River, Australia }\end{array}$ & $\begin{array}{l}0.045^{a} \\
(0.009- \\
0.111)^{b}\end{array}$ & $\begin{array}{l}0.111^{\mathrm{a}} \\
(0.027-0.321)\end{array}$ & $\begin{array}{l}0.24 \\
(0.16- \\
0.35)\end{array}$ & $\begin{array}{l}0.81 a \\
(0.20- \\
2.13)\end{array}$ & $\begin{array}{l}0.26 \\
(0.18-0.39)\end{array}$ & $\begin{array}{l}0.88^{a} \\
(0.21- \\
2.37)\end{array}$ & $\begin{array}{l}\text { Markich and } \\
\text { Brown, 1998[79] }\end{array}$ \\
\hline $\begin{array}{l}\text { St. Lawrence } \\
\text { River Mouth, USA }\end{array}$ & 0.022 & 0.0644 & 0.062 & 0.996 & 1.767 & 0.812 & $\begin{array}{l}\text { Gobeil } \\
\text { et al., 2005[80] }\end{array}$ \\
\hline $\begin{array}{l}\text { Pearl River (Urban), } \\
\text { China }\end{array}$ & $\begin{array}{l}0.127 \\
(0.010- \\
1.340)^{b}\end{array}$ & $\begin{array}{l}0.577 \\
(0.10- \\
2.64)^{b}\end{array}$ & $\begin{array}{l}0.418 \\
(0.050- \\
2.230)^{b}\end{array}$ & $\begin{array}{l}13.96 \\
(1.20-95.41)^{b}\end{array}$ & $\begin{array}{l}28.57 \\
(0.98-178.89)^{b}\end{array}$ & $\begin{array}{l}61.847 \\
(1.74-706.25)^{b}\end{array}$ & $\begin{array}{l}\text { Ouyang } \\
\text { et al., 2006[80] }\end{array}$ \\
\hline $\begin{array}{l}\text { Pearl River (Rural), } \\
\text { China }\end{array}$ & $\begin{array}{l}0.041 \\
(0.01- \\
0.13)^{b}\end{array}$ & $\begin{array}{l}0.429 \\
(0.14- \\
1.81)^{b}\end{array}$ & $\begin{array}{l}0.122 \\
(0.04- \\
0.34)^{b}\end{array}$ & $\begin{array}{l}5.358 \\
(1.28-21.65)^{b}\end{array}$ & $\begin{array}{l}7.016 \\
(0.35-29.78)^{b}\end{array}$ & $\begin{array}{l}6.008 \\
(2.38-14.21)^{b}\end{array}$ & $\begin{array}{l}\text { Ouyang } \\
\text { et al., 2006[81] }\end{array}$ \\
\hline
\end{tabular}

Table 2: Comparison of dissolved metal concentration in freshwater at Guiyu, Australia and USA ( $\mu$ g/L) Data Source: Adapted from source [82].

a Geometric mean, b Range

than that of the urbanized region of the Pearl River, suggesting a significant discharge of these metals in Nanyang [82]. Figures 6 and 7 also show the higher concentration of heavy metal $\mathrm{Pb}, \mathrm{Cd}, \mathrm{Co}, \mathrm{Cu}, \mathrm{Ni}$ and $\mathrm{Zn}$ concentrations presented in the study by Coby et.al, and also data adapted from other studies cited in [82]. Several studies attempted to establish a link between (direct and indirect) children workers in e-waste facilities and their health impact. It is currently hard to estimate to what extent children work specifically on e-waste disposal sites; however, many studies reported that children's comprising a significant proportion of all workers on these sites. The difficulty in estimation results largely from a lack of data segregation for e-waste, as a considerable knowledge base exists for child laborers working as "scavengers" or "waste-pickers" [83]. One case study cited in [83] was led by Cuadra (2005) specifically investigated heavy metals exposure of child scavengers in the city of Managua, Nicaragua. Blood analysis of children, who worked as scavengers, showed that the children working at the waste disposal site had higher levels of lead in their blood compared with the non-working reference groups. Among the child workers at the waste disposal site, as many as $28 \%$ had blood lead levels greater than the community action level of $100 \mu \mathrm{g} / \mathrm{L}$ recommended by the Centers for Disease Control and Prevention (CDC) [84]. Two other studies have reported elevated body loadings of heavy metals [85] and persistent toxic substances in children and e-waste workers, respectively, in Guiyu [86]. Huo et al. [85] studied 165 children in Guiyu and 61 children in Chendian and measured their blood lead levels (BLLs). As expected, BLLs among Guiyu children were much higher than those in the children of Chendian ( $\mathrm{p}<0.01)$. Among Guiyu children, $135(81.8 \%)$ had BLLs $>10 \mu \mathrm{g} / \mathrm{dL}$, whereas $23(37.7 \%)$ in Chendian $(\mathrm{p}<0.01)$ had high levels. Among 135 (81.8\%) Guiyu children with elevated BLLs, $62 \%$ and $20 \%$ had BLLs $>10 \mu \mathrm{g} / \mathrm{dL}$ and $20 \mu \mathrm{g} / \mathrm{dL}$ respectively, but lead levels $>45 \mu \mathrm{g} / \mathrm{dL}$ were not found in any children's blood. The BLLs of children working in Guiyu increased somewhat with age $(\mathrm{p}<0.01)$; older children tended to have higher BLLs than the younger ones. The same study found no evidence for the association in lead concentrations or prevalence of elevated BLLs differentiated by sex (both at $\mathrm{p}>0.05$ ). Compared to a study by Luo et al. [87] on children aged 1 to 5 -year living in Shantou City ( $30 \mathrm{~km}$ from Guiyu), the average BLL was 7.9 $(3.6 \mu \mathrm{g} / \mathrm{dL}$; approx. 2-time lower than that in Guiyu children. In Guiyu, it is estimated that about $80 \%$ of the children suffer from respiratory diseases [25]. Moreover, there has been a surge in cases of leukemia and high concentrations of lead in blood reported [57]. According to the China Labor Bulletin, e-waste recycling activities have contributed to elevated blood lead levels in children and high incidence of skin damage, headaches, vertigo, nausea, chronic gastritis, and gastric and duodenal ulcers [88]. Due to the existence of numerous e-wastes recycling sites in the Guiyu region is believed to be one of the most heavily chromium-polluted areas in China. Several research studies focused on levels of chromium concentrations among children and its consequent impacts on neonates. Li et al. [89] found that Umbilical cord blood chromium levels (UCBCLs) in neonates from Guiyu city had several folds higher than the normal values. A significant difference in UCBCLs in neonates was observed between Guiyu group and the control group. Based on their study, the authors concluded that, although the UCBCLs of neonates in 2007 had somewhat decreased compared with that of 2006, it was still a serious threat to neonates' health around the e-waste recycling areas [86]. In another study conducted by Xijin et al. [90] a total of 149 children from Guiyu and 146 from Chendian of the subjects enrolled in 2008 completed the questionnaires. The study found that the blood chromium levels in children corresponded to e-waste-related factors, such as occupation of either parent in, using the house as an e-waste facility, and residence adjacent to e-waste workshops. The median blood chromium in children, whose house was used as family workshops was $45.2 \mu \mathrm{g} / \mathrm{L}$, whereas blood chromium in children's house not as a family workshop was $31.1 \mu \mathrm{g} / \mathrm{L}$. Similarly, children to born to parents engaged in work related to e-waste recycling and residence adjacent to e-waste workshops, in comparison with those not related or adjacent to e-waste, had higher blood chromium levels. Besides the above mentioned ones, numerous studies imported negative impacts of heavy metals pollution on residents around the e-waste processing sites and workers. Study by Fu et al., [73] focused on resident dietary intake of heavy metals from rice sources and compared the tolerable daily intakes stipulated by the FAO/WHO standards [91] with the mean estimated daily intakes. Lead intake data was recorded (3.7 $\mu \mathrm{g} /$ day.kg.bw) slightly higher than the FAO prescribed tolerable intake of $(3.6 \mu \mathrm{g} /$ day.kg.bw). Another research conducted by Zheng et al. [92] indicated that daily intake of heavy metals from several food sources (chicken, fish, pork, rice and vegetables), house dust and groundwater. The study observed the 


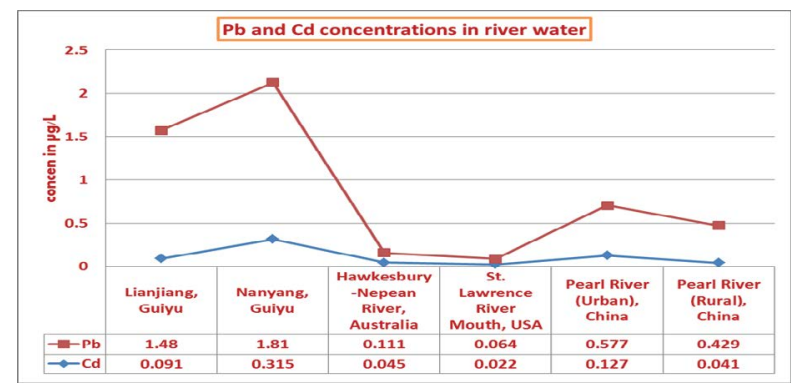

Figure 6: Comparison of $\mathrm{Pb}$ and $\mathrm{Cd}$ concentration in river waters Data Source: Adapted from source [82].

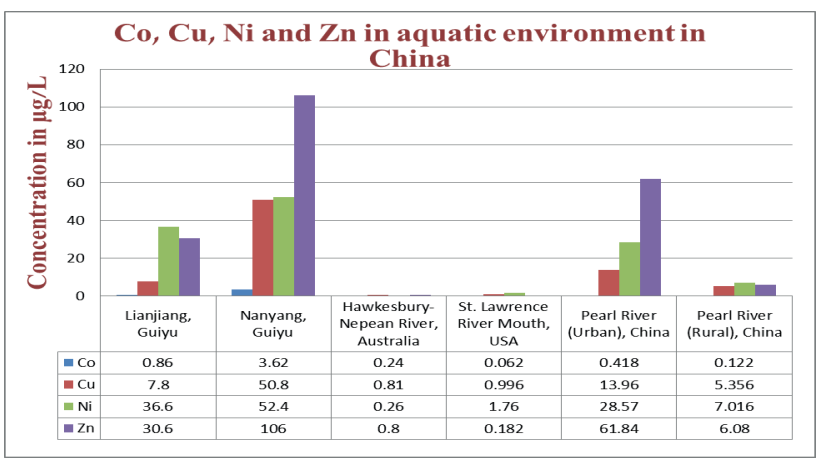

Figure 7: Comparison of $\mathrm{Co}, \mathrm{Cu}, \mathrm{Ni}$ and $\mathrm{Zn}$ concentration in river waters Data Source: Adapted from source [82].

higher daily intake, with serious health risks, particularly among the children. While Li et al. [93] evaluated the impacts of heavy metals on neonate's health; their study determined the levels of placental cadmium and cord blood cadmium. Among the 423 mothers included in the study from 2004 to 2007, a sample of 289 participants lived in Guiyu (exposed group) and 134 lived in Chaonan, located $10 \mathrm{~km}$ from Guiyu (control), and had never been exposed to e-waste pollution. The median placental cadmium was higher for Guiyu neonates than for the controls (3.61 vs. $1.25 \mu \mathrm{g} / \mathrm{L}$ ), with $25.6 \%$ of Guiyu subjects exhibiting a median cord blood cadmium that exceeded the safety limit defined by the WHO $(5 \mu \mathrm{g} / \mathrm{L})$, as compared with $14.2 \%$ of control neonates $(\mathrm{p}<0.01)$. In Guiyu, the mean placental cadmium was higher than that for controls $(0.17 \pm 0.48$ vs. $0.10 \pm 0.11 \mu \mathrm{g} / \mathrm{g}$ at $\mathrm{p}<0.05)$. The high levels of placental cadmium and cord blood cadmium were significantly associated with parents' occupational and environmental exposure to e-waste recycling pollutants. Therefore, elevated chromium levels in neonates were significantly correlated with improper e-waste recycling and disposal and its consequent effects on the environment and human health hazards. In their recent review paper Qingbin and Jinhui [94] reported that although many studies have estimated the potential daily intakes of the heavy metals in e-waste recycling sites, it should be noted that the use of data generated in surveys to estimate dietary exposure, inhalation, soil/dust ingestion and dermal exposure would likely overestimate the actual exposure. There are several other factors that can affect the daily intake. The environmental impacts associated with WEEE have translated directly into a serious public health threat. Many of these threats are already apparent in medical diagnoses and public health research. Some long-term risks may be yet to develop, and will still needs better understanding [83]. A large number of researches [85,89,95-107] have produced significant amount data on human health impacts focusing on heavy metal levels in blood, impacts of chromium exposure in neonates, effect on chromosomal aberration, BFR and thyroid hormones, elevated body burdens of PBDEs, Dioxin and PCBs, lung of children, etc. A greater part of the research attempted to establish a likely link between human health impact and the contributing pollutants from e-waste processing practices. Even so, there are concerns among researchers and policy makers to establish the direct coherent link between data and health impacts. A group of biomedical researchers published review paper in the Lancet Global Health in 2013. After rigorous screening, a sample of 165 studies were considered and assessed for eligibility. Among those 23 papers reported associations between exposure to e-waste or waste electrical and electronic equipment and physical health, mental health, neurodevelopment, and learning outcomes. After comprehensive review of those studies, the group made a note of caution that few epidemiological data, weak associations, inconsistent findings across studies, and poor understanding of biological mechanisms preclude the establishment of a causal relation between exposure to e-waste and adverse health outcomes in the assessment of evidence by conventional epidemiological approaches. However, the widespread production and use of electronic and electrical equipment, the increasing contamination of the environment, and the persistence and bioaccumulation of these chemical components and their residuals warrant special consideration that e-waste is an emerging public health concern. Evidence suggests that WEEE is significantly increasing incidences of physical injuries and chronic disease, threatening not just workers but also current residents and future generations [37]. These opinions clearly imitate others views that there is a greater need to pursue cohesive and integrated research to establish a clear link between exposures in e-waste processing and human health impact.

\section{Discussion}

\section{Challenges and opportunities ahead}

In future, managing e-waste in a sustainable approach embodies a wide variety of challenges as well as opportunities for major stakeholders e.g., consumers, businesses and national governments. However, achieving sustainability goal is not a smooth horizontal path of transition but possible if pragmatic strategies entails awareness campaign, availability of technical tools and training programs, and regional and global cooperation of all actors. There is a greater and urgent need for political pledge for integration of existing fragmental approaches through committed financial mechanism. As stated in ILO report that, e-waste is a significant cross-cutting issue with global significance, and it therefore requires a cross-sectoral implementation. Many stakeholders are involved, including industry players, governments, customs authorities, regulatory agencies, intergovernmental organizations, non-governmental organizations and civil societies. What is needed is a range of interventions, international cooperation and goal-oriented actions on e-waste [83].

Recently, the "2013 Geneva Declaration on E-Waste and Children's Health" was published to raise awareness of human health risks by exposures to e-waste. Due to the broad scope and inherent global nature of these issues, appropriate solutions are challenging to find [108]. In contrast, Schluep et al. [24] acknowledged that although the current data presented are alarming, the situation could be improved rapidly by the implementation of more benign recycling techniques and the development and enforcement of WEEE-related legislation at the national level, including prevention of unregulated WEEE exports from industrialized countries. Several national, regional and 
global schemes are in place to keep in check the challenges of e-waste. Fewer options offer a step forward towards sustainable solution e.g., Extended Producer Responsibility (EPR), Waste Take back, efforts to control illegal trafficking and StEp program to better coordinate global management of e-waste.

\section{EPR/E-waste takeback}

Extended Producer Responsibility (EPR), as a principle, emerged in academic circles in the early 1990s. It is generally seen as a policy principle that requires manufacturers to accept responsibility for all stages in a product's lifecycle, including EoL management. There are three primary objectives of the EPR principle: Manufacturers shall be incentivized to improve the environmental design of their products and the environmental performance of supplying those products; Products should achieve a high utilization rate; and Materials should be preserved through effective and environmentally-sound collection, treatment, reuse, and recycling. Often EPR is narrowly defined as to be almost a synonym with a mandatory take-back system or some sort of financial responsibility. The establishment of feedback loops from the downstream EoL management into the upstream design phase is at the core of the EPR principle, and is what can distinguish EPR policies from the implementation of a mere take-back system [29]. Gregory et al. [109], proposed e-waste take-back system as means of solution, whose main functions are collection, processing, system management, and financing scheme. Meanwhile, several examples of current system models have been presented in the United States (such as California, Maine, and Minnesota), and Belgium, France, and Germany, in the EU. Even though some successful stories of e-waste take-back system currently exist, but several challenges still remain unresolved including (i) how to balance the harmonization between manufacturers and recyclers with respect to finance, operations, technologies, market, and so forth?, (ii) how to deal with different business models of stakeholders from various industries?, (iii) how to determine the number of policy in law, leaving others to be industrial standards?, and (iv) how to ensure that obligations are met by the stakeholders? [26]. Up until now, few developed countries took initiatives to embrace EPR for e-waste management with some success, while challenges still remains to achieve complete realization of EPR principles. Over 25 nations have some form of EPR program. EPR is most commonly applied for packaging waste, the most famous being Germany's packaging ordinance. However, batteries, electronic and electrical appliances and automobiles are also increasingly scrutinized under EPR programs. Electronic and electrical products are a major focus of EPR policies around the world [110] especially in Europe, where over the last couple of years, several countries have favored an EPR based e-waste policy. One of the holistic EPR strategies has implemented in Switzerland: over 10 years of success in a close loop system - very little waste into land-fill and $75 \%$ of the material was returned to the raw materials cycle. Figure 8 illustrates the circular flow of materials aims to optimize a closed loop material cycle, with the raw materials converted to finished EEE going through the retail and consumption stages and then at the end-of-life being collected and recycled to be put back into the production of new goods [111]. Some rapidly emerging economies, such as China, India and Indonesia have started to develop EPR programs even though these are generally not yet fully implemented and functioning. Malaysia and Thailand are also embarking the path towards EPR for e-waste, although these initiatives generally rely on voluntary participation of producers [114].

\section{Emergence of StEP}

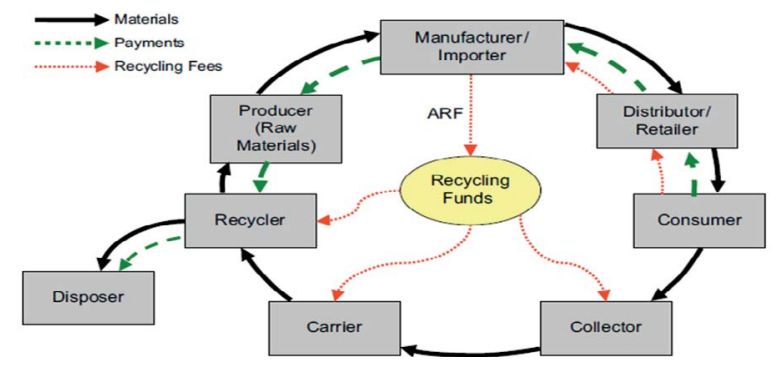

Figure 8: Flow of materials and finances in the Swiss e-waste management system, Source: Adapted from [111].

Another successful effort is the establishment of StEp, which became active in 2007 , is coordinated by the UN University, the thinktank and research arm of the UN that hosts the Step Secretariat. Since commencement, the (StEP) initiative in solving the e-waste problem is well positioned to make a difference towards the development and practical implementation of sustainable solutions [6]. One of the pragmatic initiatives of StEp is to bring major stockholders on board e.g., IGO's, industry, governments, NGOs, environmental groups and academia to achieve common goals of developing and implementing e-waste strategies. The shared expertise and common vision of StEp's members focus on seven key areas: Reducing the materials used in manufacturing; Reusing equipment or components when practical; Refurbishing when possible; Recovering materials from obsolete equipment; Recycling the biggest possible level of materials; Developing policy recommendations for sustainable solutions and Administer trainings for key stakeholder groups. StEP's five Task Forces are advancing the e-waste agenda on many fronts. StEp takes a life-cycle approach to the global e-waste dilemma looking at the areas policy, redesign, reuse, recycle and capacity building. For 2014 and 2015, Step members have agreed to work on six projects to remaining Task Force work. Each project is led by two Step members, usually one representative from industry and one non industry actor [6]. Global initiatives have already been enacted at both the voluntary standard and regulatory levels in recognition of the importance in the responsible management of e-waste [113]. Over the past decade, China has made great advances to advocate better e-waste collection and recycling in both public and private sectors. There is a visible increase in domestic and foreign investments into recycling field, accompanied by encouraged transfer of international recycling technologies and western waste management principles [114]. Under the auspices of EU, the UN-StEp program at different steps (e.g., capacity building, policy intervention) are undergoing in several Asian and African countries. At this outset as one of the largest producers and processor of e-waste, China necessitates to fill-up the loophole of their regulatory instruments and be proactive in collaborating with the global community to deal with massive e-waste related environmental issues. A schematic diagram of global cooperation is proposed in Figure 9. Minute details for the suggested global cooperation may be debatable, the contemplations suggested above for the life cycle of electronics has to be improved significantly to avoid an accelerated loss of scarce raw materials, emission of toxics into the environment, and most importantly to protect human health and ecosystem services.

\section{Conclusion}

E-waste is omnipresent. It is characterized by its unusual chemical composition and the difficulties associated with determining its mass 
Citation: Shamim A, Mursheda AK, Rafiq I (2015) E-Waste Trading Impact on Public Health and Ecosystem Services in Developing Countries. Int J Waste Resour 5: 188. doi: $10.4172 / 2252-5211.1000188$

Page 10 of 12

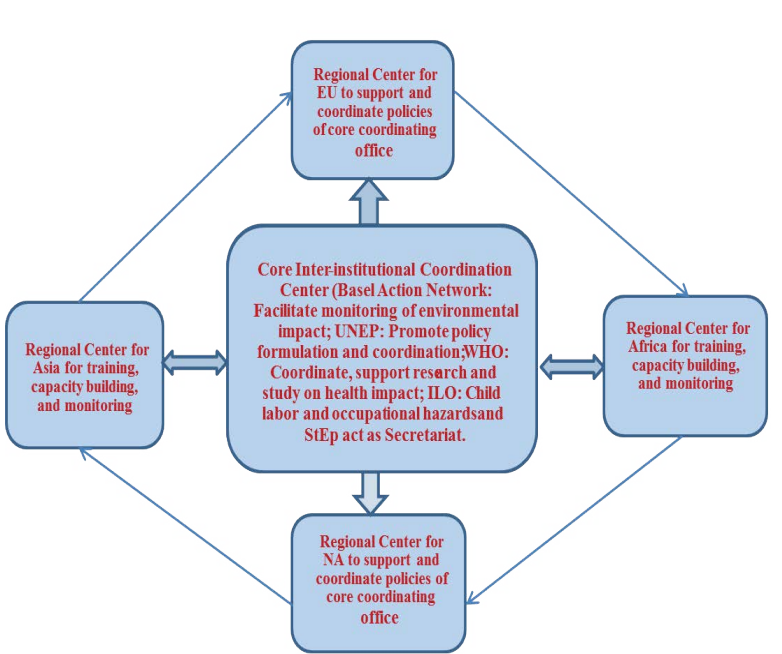

Figure 9: Schematic proposed plan for future collaboration among major stockholders.

and flux at both local and global scales. Contamination associated with e-waste has already caused considerable environmental degradation in the developing countries and adversely affected the health of the people who live in and around e-waste facilities [10]. The quantities of e-waste generated are predicted to grow substantially, both in industrialized countries and in the developing countries. The rich countries often legally or illegally divert this problem from their own backyards to the premises of the developing countries [115]. The hidden flow of e-waste that results environmental damage in the backyards and scrapyards of the developing countries. It is quite perceptible from present and future scenarios of e-waste generation and hidden flow in the developing countries, mostly Asian and African continents will be adversely affected. There may be a shift of hub for informal recycling and processing from Guiyu, China to Ghana or Nigeria, however, challenges with impact on human health and ecosystem services will continue to exacerbate with hidden flow and improper recycling practices. One of the major challenges in achieving sustainable of e-waste management is to organize integration of formal and informal generation and process and establish better understanding on human health impact. As stated, some of the strategies and policy options are imparting piecemeal positive impacts but there are greater need to consolidation and integration. As observed in StEp green report that while the promotion and capacity-building of effective and efficient take-back solutions for End of Life (EoL) material is vital, the paper noted that there should also be a concerted effort to focus more on the reduction of e-waste volumes and the repair/reuse of EEE. Although several initiatives have been identified, especially by not-for-profits and the informal sector, there are few examples of public policy initiatives that have been successful [29]. It seems that there are enough missing links on policy initiatives among producers and recipient countries. Unless collaborative efforts are appropriated to consolidate cooperation among the major stockholders, sustainable e-waste management will not achieve complete success. To cultivate sustainable e-waste management practices: intensive awareness campaign; capacity building to prevent illegal trafficking; and proper technical training of formal e-waste processing practices must be ensured through collaborative approach. Poverty plays a crucial role in the exponential growth of informal sector. Also to prevent further growth of informal economy in e-waste management an economic tool to support growth of processed e-waste material market must be established.

\section{References}

1. UNEP (2007) E-waste Inventory Assessment Manual volume I.

2. UNEP DEWA/GRID-Europe (2005) E-waste, the hidden side of IT equipment's manufacturing and use, in: Early Warning on Emerging Environmental Threats, (Chapter 5).

3. UNU, (2013) Solve the E-waste Problem (StEP), Massachusetts Institute of Technology (MIT), National Center for Electronics Recycling (NCER). World e-waste map reveals national volumes, international flows.

4. EPA 530-S-11-001, May (2011) "Electronics Waste Management in the United States.

5. Terazona A, Murakami S, Abe N, Inanc B, Moriguchi Y, et al. (2006), Current status and research on E-waste issues in Asia, J. Mater. Cycles Waste Management 8: 1-12.

6. StEP initiative, StEP Annual Report (2013/14)

7. Li J, Tian B, Liu T, Liu H, Wen X, et al. (2006) Status quo of e-waste management in mainland China, J. Mater. Cycles Waste Management 8:13-20.

8. Ladou J, and Lovegrove S (2008) Export of electronics equipment waste. Int J Occup Environ Health 14: 1-10

9. Diaz-Barriga $F$ (2013) Evidence-based intervention programs to reduce children's exposure to chemicals in e-waste sites. Discussion paper for WHO Working Meeting on e-waste and children's health. 1-90

10. B. Robinson (2009) E-waste: An assessment of global production and environmental impacts, Science of the Total Environment 408: 183-191.

11. UNEP (2009) Basel Convention on the Control of Transboundary Movements of Hazardous Wastes and their Disposal. United Nations Environment Programme.

12. Schneider F, Enste DH (2003) The Shadow Economy, an international survey. Cambridge: Cambridge University Press, UK.

13. CBC News, (2007) "How much e-waste do you dump? Cheryne's Diary,".

14. Lundgren $\mathrm{K}$ (2012) The global impact of e-waste: addressing the challenge, International Labour Office (ILO), Geneva.

15. UNEP (2006) Call for Global Action on E-waste. United Nations Environment Programme.

16. Cobbing M (2008) Toxic tech: not in our backyard, uncovering the hidden flows of e-waste, Greenpeace International, Amsterdam.

17. UNU (2007) Review of Directive 2002/96 on Waste Electrical and Electronic Equipment (WEEE). Final Report to European Commission, Bonn.

18. Duffert C, Brune MN, Prout K Background document on exposures to e-waste World Health Organization (WHO) Geneva, Switzerland.

19. Global E-Waste Management Market (2011 - 2016), Report Code: SE 1588 Retrieved from: marketsandmarkets.com, Publishing Date: August 2011

20. Gagliardi D, Mirabile M Overview of OSH issues related to the e-waste management: World Health Organization (WHO), Geneva, Switzerland.

21. Deng W J, Louie P, Liu W, Bi X, Fu J et al. (2006) Atmospheric levels and cytotoxicity of PAHs and heavy metals in TSP and PM2.5 at an electronic waste recycling site in southeast China Atmos. Environ. 40: 6945-55.

22. Macauley M, Palmer K, Shih JS (2003) Dealing with electronic waste: modeling the costs and environmental benefits of computer monitor disposal. Journal of Environmental Management 68: 13-22.

23. Brigden K, Labunska I, Santillo D, Allsopp M (2005) Greenpeace Research Laboratories, Department of Biological Sciences, University of Exeter, Exeter EX4 4PS, UK, Report on recycling of electronic wastes in China and India: Workplace \& Environmental Contamination.

24. Schluep M, Hageluken C, Kuehr R, Magalini F, Maurer C et al. (2009) Recycling - From E-waste to Resources, Report prepared by Swiss Federal Laboratories for Materials Testing and Research, Umicore Precious Metal Refining and the United Nations University.

25. Sepúlveda A, Schluep M, Renaud FG, Streicher M, Kuehr R (2010) A review of the environmental fate and effects of hazardous substances released from 
Citation: Shamim A, Mursheda AK, Rafiq I (2015) E-Waste Trading Impact on Public Health and Ecosystem Services in Developing Countries. Int J Waste Resour 5: 188. doi: $10.4172 / 2252-5211.1000188$

Page 11 of 12

electrical and electronic equipments during recycling: Examples from China and India, Environmental Impact Assessment Review 30:28-41.

26. Khurrum M, Bhutta Z, Omar A, Yang X (2011) Electronic Waste: A Growing Concern in Today's Environment. Economics Research International 11: 1-8.

27. Consumer Electronic Association ${ }^{R}$ (2012) Corporate Report.

28. Global E-Waste Management Market - Size, Industry Analysis, Trends, Opportunities, Growth and Forecast, 2013 - 2020. Allied Market Research, Published: Jan-2015

29. Solving the E-Waste Problem (2015) Green Paper E-waste Prevention, Takeback System Design and Policy Approaches, ISSN: 2219-6579.

30. Lu C, Lin Z, Yongguang Z, Wanxia R, Mario (2015) An overview of e-waste management in China. Journal of Material Cycles and Waste Management 17 $1-12$

31. Electronic Waste, http://www.newworldencyclopedia.org/entry/Electronic waste, ( Cited in news article in world encyclopedia and retrieved on January 1, 2015)

32. Greenpeace International (2009) where dos e-waste end up?

33. Kuper J, Hojsik M (2008) Poisoning the Poor Electronic Waste in Gahana, Greenpeace International, Amsterdam, Netherlands.

34. Chan JKY, Wong MH (2012) A review of environmental fate, body burdens, and human health risk assessment of PCDD/Fs at two typical electronic waste recycling sites in China. Science of Total Environment 463-464:1111-23.

35. Schmidt C (2002) e-Junk explosion Environ. Health Perspect. 110:A188-A194.

36. Schmidt CW (2006) Unfair trade E-waste in Africa, Environ. Health Perspect. 114: A232-A235.

37. Kristen G, Fiona C G, Peter D, Marie B, Maria N (2013) Health consequences of exposure to e-waste: a systematic review. Lancet Glob Health 1: 350-361.

38. Gu Z, Feng J, Han W, Wua W, Fu J (2010) Characteristics of organic matter in PM from an e-waste dismantling area in Taizhou, China, Chemosphere 80:800-806

39. Wilson DC, Velis C, Cheeseman C (2006) Role of informal sector recycling in waste management in developing countries. Habitat International $30: 797-808$.

40. Linda L (2010), Managing Electronic Waste: Issues with Exporting E-Waste CRS Report for Congress, Prepared for Members and Committees of US Congress.

41. Electronic Take back Coalition, (2012) $\mathrm{E} \square$ Waste Facts and Figures

42. Electronic Take back Coalition, ( 2014) E-Waste Facts and Figures.

43. EPA (2014) data from "Municipal Solid Waste Generation, Recycling and Disposal in the United States, 2012

44. Robert Tonetti, (October 2007) EPA Office of Solid Waste, presentation materials, "EPA's Regulatory Program for E-Waste,".

45. European Union. EU Directive 2002/95/EC of the European Parliament and of the Council of 27 January 2003 on the restriction of the use of certain hazardous substances in electrical and electronic equipment.

46. National People Congress (2006) Administrative measures on the control of pollution caused by electronic information products.

47. Basel Convention, Decisions adopted by the Conference of the Parties to the Basel Convention on the Control of Trans-boundary Movements of Hazardous Wastes and their Disposal : COP 6 - 10 and ExCOPs, Compiled in 2012.

48. UNEP/CHW/OEWG/6/21, (2007) Open-ended Working Group of the Base Convention on the Control of Trans-boundary Movements of Hazardous Wastes and Their Disposal Sixth session Geneva, 3-7 September 2007.

49. Exporting harm: the high-tech trashing of Asia (2002) Prepared by BAN and SVTC - The Basel Action Network and Silicon Valley Toxics Coalition.

50. GAO (2008), EPA Needs to Better Control Harmful U.S. Exports through Stronger Enforcement and More Comprehensive Regulation, GAO-08-1044.

51. House Committee on Foreign Affairs, Subcommittee on Asia, the Pacific and the Global Environment, "Exporting Toxic Trash: Are We Dumping Our Electronic Waste on Poorer Countries?" September 17, (2008).

52. UNEP, GSA and White House Council on Environmental Quality, (2014)
Interagency Task on Electronics Stewardship.

53. Computer Aid International (2010) WEEE Ver. 2.0: What Europe must do, Special Report Series: ICT and the Environment, Report 2.

54. Final Report (2014) ITU-D Study group 1, Strategies and policies for the proper disposal or reuse of telecommunication/ICT waste material.

55. Lin Weia and Yangsheng Liub (2012) Present status of e-waste disposal and recycling in China, Procedia Environmental Sciences 16: 506 - 514

56. The State Council (2004) The measures for the Administration of Permit for Operation of Dangerous Wastes [Z]

57. Tsydenova O, Bengtsson M (2011) Chemical hazards associated with treatmen of waste electrical and electronic equipment. Waste Management 31:45-58.

58. EFFACE (2015), A case study on illegal e-waste export from the EU to China, European Union Action to Fight Environmental Crime.

59. INTERPOL, May (2009) Electronic Waste and Organized Crime: Assessing the link, Phase II report for the pollution crime working group.

60. INTERPOL, (2010) "International experts outline global strategy to tackle e-waste threat at INTERPOL meeting." Media Release 25 May.

61. Ongondo F O, Williams I D, Cherrett T J (2011) How are WEEE doing? A global review of the management of electrical and electronic wastes, Waste Management 31: 714-30.

62. Environmental Investigation Agency (2011) System failure: The UK's harmful trade in electronic waste.

63. UNDOC (2013) Transitional Organized Crime Threat Assessment- Asia and the Pacific, Chapter 9 Illicit trade in electrical and electronic waste (e-waste) from the world to the region.

64. UNEP (2015) A RAPID RESPONSE ASSESSMENT: WASTE CRIME WASTE RISKS GAPS IN MEETING THE GLOBAL WASTE CHALLENGE, ISBN: 978 82-7701-148-6.

65. The Times, "Britain's dirty little secret as a dumper of toxic waste", July 18 2009 ( Cited in SYSTEM FAILURE The UK's harmful trade in electronic waste, ENVIRONMENTAL INVESTIGATION AGENCY (EIA), 2011 Report).

66. INTERPOL (2013) INTERPOL operation targets illegal trade of e-waste in Europe, Africa. [Online] 25/02/2013.

67. Strategic Approach to International Chemicals Management (SAICM) (2009) Background information in relation to the emerging policy issue of electronic waste, paper presented at the International Conference on Chemicals Management, Geneva, 11-15 May (SAICM/ICCM.2/INF36).

68. Jing Yuan, Lan Chen, Duohong Chen, Huan Guo, Xinhui B, et al. (2008) Elevated serum polybrominated diphenyl ethers and thyroid-stimulation hormone associated with lymphocytic micronuclei in Chinese workers from an e-waste dismantling site Environ Sci Technol 42:2195-2200.

69. Wen S, Yang F, Gong Y, ZhangX, Hui Y, Li J, et al. ( 2008) Elevated levels of urinary 8-hydroxy-2'-deoxyguanosine in male electrical and electronic equipment dismantling workers exposed to high concentrations of polychlorinated dibenzo- -dioxins and dibenzofurans, polybrominated diphenyl ethers and polychlorinated biphenyls Environ. Sci. Technol. 42:4202-4207.

70. Qiang Liu, Jia Cao, Ke Qiu Li, Xu Hong Miao, Guang Li, et al. (2009) "Chromosomal aberrations and DNA damage in human populations exposed to the processing of electronics waste" Environmental Science and Pollution Research 16:329-338.

71. Bina Rani, Upma Singh, Raaz Maheshwari, A K Chauhan (2012) PERILS OF ELECTRONIC WASTE: ISSUES AND MANAGEMENT STRATEGIES, Journa of Advanced Scientific Research 3:17-21.

72. GAO (2005) Electronic Waste - Observation on the Role of the Federal Government in Encouraging Recycling and Reuse.

73. Fu J, Zhou Q, Liu J, Liu W, Wang T, et al. (2008) High levels of heavy metals in rice (Oryza sativa L.) from a typical E-waste recycling area in southeast China and its potential risk to human health Chemosphere 71:1269-75.

74. Wong M, Wu S, Deng W, Yu X, Luo Q, et al. (2007) Export of toxic chemicals: a review of the case of uncontrolled electronic-waste recycling, Environ. Pollution 149:131-40.

75. Chen D, Bi X, Zhao J, Chen L, Tan J, et al. (2009) Pollution characterization and diurnal variation of PBDEs in the atmosphere of an E-waste dismantling region 
Citation: Shamim A, Mursheda AK, Rafiq I (2015) E-Waste Trading Impact on Public Health and Ecosystem Services in Developing Countries. Int J Waste Resour 5: 188. doi: $10.4172 / 2252-5211.1000188$

Environ. Pollution 157:1051-1057.

76. BASEL ACTION NETWORK (2002) Exporting Harm: The High-Tech Trashing of Asia (Seattle, WA: Basel Action Network).

77. WHO, The Geneva declaration on e-waste and children's health.

78. Chi X, Streicher-Porte M, Wang MYL, Reuter MA (2011) Informal electronic waste recycling: a sector review with special focus on China. WHO, The Geneva declaration on e-waste and children's health. Waste Management 31:731-741.

79. Markich SJ, Brown PL (1998) Relative importance of natural and anthropogenic influences on the fresh surface water chemistry of the Hawkesbury- Nepean River, South-Eastern Australia. The Science of the Total Environment 217:201230

80. Gobeil C, Rondeau B, Beaudin L, (2005) Contribution of municipal effluents to metal fluxes in the St. Lawrence River. Environmental Science and Technology 39:456-464.

81. Ouyang TP, Zhu ZY, Kuang YQ, Huang NS, Tan JJ, et al. (2006) Dissolved trace elements in river water: spatial distribution and the influencing factor, a study for the Pearl River Delta Economic Zone, China. Environmental Geology 49:733-742.

82. Coby SC, Wong, Nurdan S.,Duzgoren-Aydin, Adnan Aydin, Ming Hung Wong, (2007) Evidence of excessive releases of metals from primitive e-waste processing in Guiyu, China, Environmental Pollution 148: 62-72.

83. ILO (2012) Report on The global impact of e-waste: Addressing the challenge, edited by Karin Lundgren, (Accessed on 12 March 2015).

84. Cuadra SN (2005) Child labour and health hazards: Chemical exposure and occupational injuries in Nicaraguan children working in a waste disposal site. Licentiate Thesis. Lund, Lund University, Faculty of Medicine.

85. Huo X, Peng L, Xu X J, Zheng L K, Qiu B et al. (2007) Elevated blood lead levels of children in Guiyu, an electronic waste recycling town in China Environmental Health Perspective 115:1113-1117.

86. Bi XH, Thomas GO, Jones KC, Qu WY, Sheng GY, et al. (2007) Exposure of electronics dismantling workers to polybrominatetd diphenyl ethers, polychlorinated biphenyls, and organochlorine pesticides in South China. Environ. Sci. Technol, 41:5647-5653.

87. Luo W H, Zhang Y, Li H (2003) Children's blood lead levels after the phasing out of leaded gasoline in Shantou, China. Environ Health 58:184-187.

88. China Labour Bulletin (2005) “The plight of China's e-waste workers”, 15 Aug.

89. Li Y, Xu X, Liu J, Wu K, Gu C, et al. (2008) The hazard of chromium exposure to neonates in Guiyu of China. Science of Total Environment 403:99-104.

90. Xijin Xu, Taofeek Akangbe Yekeen, Junxiao Liu, Bingrong Zhuang, Weiqiu Li, et al. (2015) Chromium exposure among children from an electronic waste recycling town of China, Environ Science Pollution Research 22:1778-1785.

91. World Health Organization (2011) Evaluation of Certain Food Additives and Contaminants: Seventy-fourth Report of the Joint FAO/WHO Expert Committee on Food Additives.

92. Zheng J, Chen K.H, Yan X, Chen S.J, Hu G.C, et al. (2013) Heavy metals in food, house dust, and water from an e-waste recycling area in South China and the potential risk to human health. Ecotoxicol Environ Saf 96:205-212.

93. Li Y, Huo X, Liu J, Peng L, Li W, et al. (2011) Assessment of cadmium exposure for neonates in Guiyu, an electronic waste pollution site of China. Environ Monitoring Assessment 177:343-351.

94. Qingbin Song and Jinhui Li (2015) A review on human health consequences of metals exposure to e-waste in China. Environmental Pollution 196:450-461.

95. Guo Y, Huo X, Li Y, Wu K, Liu J, Huang J, et al. (2010) Monitoring of lead, cadmium, chromium and nickel in placenta from an e-waste recycling town in China. Sci Total Environ 408:3113-7.

96. Guo Y, Huo X, Wu K, Liu J, Zhang Y, et al. (2012) Carcinogenic polycyclic aromatic hydrocarbons in umbilical cord blood of human neonates from Guiyu, China, Science of Total Environment 427-28:35-40.

97. Han G, Ding G, Lou X, Wang X, Han J, et al. (2011) Correlations of PCBs, dioxin, and PBDE with TSH in children's blood in areas of computer e-waste recycling. Biomed Environ Science 24:112-6.

98. Liu Q, Cao J, Li KQ, Miao XH, Li G, et al. (2009) Chromosomal aberrations and
DNA damage in human populations exposed to the processing of electronics waste, Environ Science Pollution Research International 16: 329-38.

99. Liu J, Xu X, Wu K, Piao Z, Huang J, et al. (2011) Association between lead exposure from electronic waste recycling and child temperament alterations, Neurotoxicology 32: 458-64

100.Li Y, Xu X, Wu K, Chen G, Liu J, et al. (2008) Monitoring of lead load and its effect on neonatal behavioral neurological assessment scores in Guiyu, an electronic waste recycling town in China. J Environ Monitoring 10:1233-8.

101. Wang $\mathrm{H}$, Zhang Y, Liu Q, Wang F, Nie J, et al. (2010) Examining the relationship between brominated flame retardants (BFR) exposure and changes of thyroid hormone levels around e-waste dismantling sites. Int $\mathrm{J}$ Hyg Environ Health 213: $369-80$.

102. Wu K, Xu X, Liu J, Guo Y, Li Y, et al. (2010) Polybrominated diphenyl ethers in umbilical cord blood and relevant factors in neonates from Guiyu, China. Environ Sci Technol 44:813-9.

103. Wu K, Xu X, Peng, Liua J, Guo Y, Huo X. (2012) Association between maternal exposure to perfluorooctanoic acid (PFOA) from electronic waste recycling and neonatal health outcomes. Environ Int, 48:1-8.

104. Xu X, Yang H, Chen A, Zhou Y, Wu K, et al. (2012) Birth outcomes related to informal e-waste recycling in Guiyu, China. Reprod Toxicol, 33: 94-8.

105. Yuan J, Chen L, Chen D, Guo H, Bi X, et al. (2008) Elevated serum polybrominated diphenyl ethers and thyroid stimulating hormone associated with lymphocytic micronuclei in Chinese workers from an E-waste dismantling site. Environ Sci Technol 42: 2195-200.

106. Zhang J, Jiang Y, Zhou J, Wu B, Liang Y, et al. (2010) Elevated body burdens of PBDEs, dioxins, and PCBs on thyroid hormone homeostasis at an electronic waste recycling site in China. Environ Sci Technol 44:3956-62.

107. Zheng G, Xu X, Li B, Wu K, Yekeen TA, et al. (2013) Association between lung function in school children and exposure to three transition metals from an e-waste recycling area. J Expo Sci Environ Epidemiol 23: 67-72.

108. Alabaster G, Ansong K, Bergman A, Birnbaum L, Noel M, et al (2013). The Geneva Declaration on E-waste and Children's Health. World Health Organization.

109. Gregory F, Magalini R, Kuehr K, Huisman J (2009) "E-wastetake-back system design and policy approaches," Solving the e-Waste Problem (StEP), White Paper.

110. Fishbein B, (1998). EPR what does it mean? Where is it headed? Pollution Prevention Review, 8(4): 43-55.

111. Khetriwal DS, Kraeuchi $P$, Widmer R (2009) Producer Responsibility for E-Waste Management: Key Issues for Consideration - Learning from the Swiss Experience Journal of Environmental Management 90: 153-65.

112. The State of Play on Extended Producer Responsibility (2014) Opportunities and Challenges, Issue Paper, Global Forum on Environment: Promoting Sustainable Materials Management through Extended Producer Responsibility (EPR), 17-19, Tokyo, Japan.

113. Solving the E-Waste Problem (2014) White Paper, Recommendations for Standards Development for Collection, Storage, Transport and Treatment of E-waste, June 2014.

114. Shinkuma T, Huong NTM (2009) The flow of e-waste material in the Asian region and a reconsideration of international trade policies on e-waste. Environmental Impact Assessment Review 29 : 25-31.

115. Green Peace, Toxic Tech: Not in Our Backyard Uncovering the Hidden Flows of e-Waste, 2008. 